\title{
3D Geoelectrical Resistivity Mapping of Tourmaline-Rich Pegmatite in AngwanDoka, Nassarawa State, Northcentral Nigeria
}

\author{
O. A. Oyonga ${ }^{1}$, E. Kudamnya ${ }^{2}$, S. I. Ugar $^{3}$ \\ ${ }^{1,2,3}$ Department of Geology, University of Calabar, Calabar, Nigeria
}

\begin{abstract}
D geoelectrical resistivity survey was carried out using the Multiple Vertical Electrical Sounding (MVES) along profile lines to determine the extent of mineralized tourmaline-rich pegmatite within a mining site in Angwan Doka community in Kokona Local Government Area, Nassarawa State, Nigeria. A total of 61 out of 90 soundings within a grid area which covered $200 \mathrm{~m}^{2}$ were selected for convenience of modeling. Resistivity data were modeled using a combination of manual curve matching, data inversion and iteration with IP2WIN software, and 3D data modeling using rockworks software. This integrated approach with a resulting 3D model revealed a major trend of the pegmatite in the NE-SW direction which is in line with the overall regional structural strike in the region. The method can therefore be applied extensively for other related subsurface resistivity investigations.
\end{abstract}

Keywords: 3D model, Tourmaline, Pegmatite, IP2win, Resistivity, Schlumberger

\section{Introduction}

Electrical methods utilize direct currents or low frequency alternating currents to investigate the electrical properties of the subsurface. Electrical resistivity is a fundamental and diagnostic physical property that can be determined by a wide variety of techniques, including electromagnetic induction [1]. The resistivity method is used in the study of horizontal and vertical discontinuities in the electrical properties of the ground, and also in the detection of threedimensional bodies of anomalous electrical conductivity. It is routinely used in engineering and hydrogeological investigations to investigate the shallow subsurface geology. In the electrical resistivity surveying method, artificiallygenerated electric current $(I)$ is passed into the ground through two earth connections (electrodes) and the voltage (potential difference $(V)$ is measured across a second pair of electrodes at the surface. The ratio of voltage to current, is the resistance that when multiplied by a factor which takes into account the spacing between the electrodes, gives a parameter known as the apparent resistivity. When the measurement is made over a homogeneous surface, the apparent resistivity is equal to the true resistivity of the ground. However, when the resistance is made over a complicated subsurface structure, the apparent resistivity is a weighted average of the resistivities of the various rocks below the surface [2-4]. Deviations from the pattern of potential differences expected from homogeneous ground provide information on the form and electrical properties of subsurface inhomogeneities [5]. Advancements in software packages have provided opportunities for subsurface modeling of physical properties in 3 dimensions [6], and resistivity is not an exception. For example quasi-3D modeling of resistivity data has been achieved by merging the results from a number of sections acquired and inverted using $2 \mathrm{D}$ resistivity imaging [7]. An attempt has been made in this study to model subsurface resistivity in 3D to reveal the trend and extent of tourmaline-rich pegmatite in AngwanDoka, Nassarawa State of Nigeria. The area investigated is part of an existing mining site in AngwanDoka community in Kokona Local Government
Area of Nassarawa State in Northcentral Nigeria. It is characterized by significant exposure of tourmaline-rich pegmatite with ongoing wildcat pit mining by local artisans (plate. 1). Mineralization patterns can sometimes be very deceptive even when one may likely assume a general trend based on structural investigation of the area of interest. Reports from geostatistical studies have shown that minerals are sometimes disseminated, i.e. without following a regular trend within a deposit. However, there will always be an overall trend in the sample distribution. The sample value is expected to vary from area to area in the deposit. Some areas are expected to be rich, and some to be poor [8]. The unguided exploitation of this gem is a serious cause for concern, as rich zones of mineralization may be bypassed, while zones which ought to have been avoided may be encountered during the mining process. It is therefore imperative to carry out geophysical investigation in the search for minerals to identify prospective zones within the host rock, and to offer valuable advice on the best areas and best way to mine. The electrical resistivity method which has gained popularity in a wide range of applications including measurements of depth to bedrock, environmental investigation of contamination, groundwater investigations, mineral exploration and archaeology, is a valuable and sensitive tool that can be used to delineate the contrasts in the physical properties of the rocks, in this case the resistivity of rocks. Tourmaline which is the mineral of interest here like some other minerals may not have significant or outstanding physical properties due to either the disseminated nature or low concentration, and thus may not allow for significant contrast in physical properties with the host rock to be revealed. In these and similar cases, geophysicists must rely on detecting rocks that are associated with the minerals, or other minerals with significant physical properties that occur in association with the mineral of interest. The application here is the use of a 3D resistivity modeling approach to produce subsurface images of the area under investigation to show the contrast between the generic migmatite (host rock) and the pegmatite which is the rock with high potentials of tourmaline mineralization in the area of investigation. 


\section{International Journal of Science and Research (IJSR) ISSN (Online): 2319-7064}

Index Copernicus Value (2015): 78.96 | Impact Factor (2015): 6.391

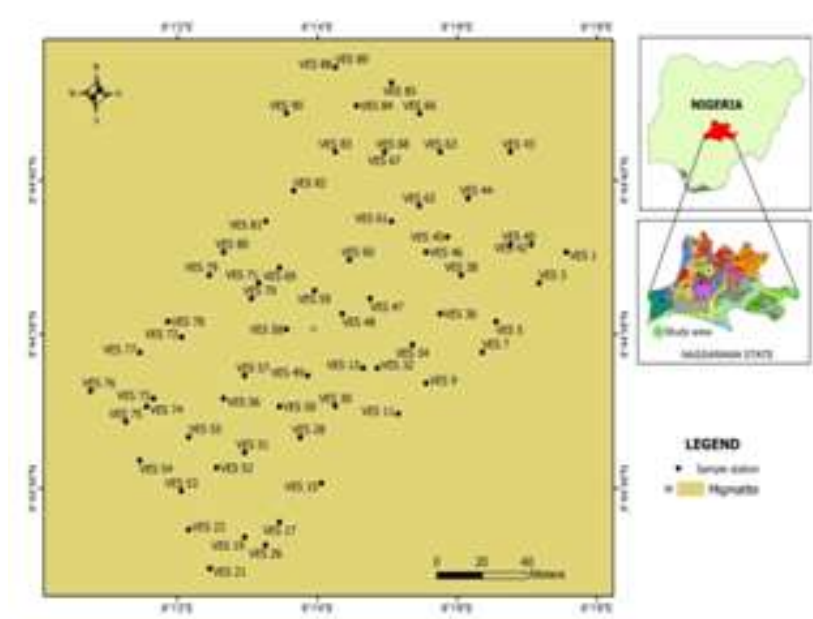

\section{Literature Survey}

\section{Location and Geology of Study Area}

The study area falls within Longitudes 391843E and 392094E, and Latitudes $966477 \mathrm{~N}$ and $966707 \mathrm{~N}$ (all in Universal Transverse Mercator, UTME) in AngwanDoka community in Kokona LGA of Nassarawa State in Northcentral Nigeria (Fig. 1). It is accessed through an offset road, about $10 \mathrm{~km}$ from the major Keffi-Akwanga road. The dominant rock type in this area is migmatite. Frequently, veins of pegmatite and quartz occur as intrusions in the host rock. Generally, Nassarawa State is composed of both basement and sedimentary rocks with the southern end forming part of the low plains of the Benue valley composed mostly of sandstones, while the high land areas towards the northern half are made up of basement rocks. The topography is undulating with lowlands and a network of hills developed on granites, migmatites, pegmatites and gneisses. A variety of solid minerals and gemstones including Tin, Tantalite, Lead, Salt, Tourmaline, Aquamarine and Galena are found in the state which makes it one of the richest in Nigeria in terms of mineral resources. Most of the gemstones are hosted within pegmatite veins that occur as intrusions in the host rocks which maybe granites, gneisses and migmatites. The high mineralization in some parts of the State is associated with the lead-zinc mineralization of the Benue Trough and with ancient volcanic activities evident in worn volcanic cones around the salt-mining village of Awe.

The State is characterized by tropical sub-humid climate with two distinct seasons (the wet and dry). The wet season spans from the beginning of May and ends in October, while the dry season stretches from November to April. The Figure1: Nigeria map showing Nassarawa State and the base map of study area showing survey stations.

annual rainfall figures range from $1100 \mathrm{~mm}$ to about $2000 \mathrm{~mm}$, and about $90 \%$ of the rain falls between May and September, with the highest amount recorded between the months of July and August. Temperatures are generally high during the day, particularly between the months of March and April. The mean monthly temperatures in the state range between $20^{\circ} \mathrm{C}$ and $34^{\circ} \mathrm{C}$, with the hottest months being March/April and the coolest months being December/ January.
Nassarawa State falls within the Guinea savannah vegetation zone of Nigeria, with characteristic sparse forests and dominant grassland. The people are mostly farmers with interest in cultivating mango, shea butter, citrus, locust bean, ginger, garlic, banana etc.

The State is drained by several fast flowing streams and rivers that take their provenance from the Jos plateau and flow into the River Benue which marks the state's southern boundary. Prominent among these are the Meda, Dep, Ayini, and Farin Ruwa rivers [9].

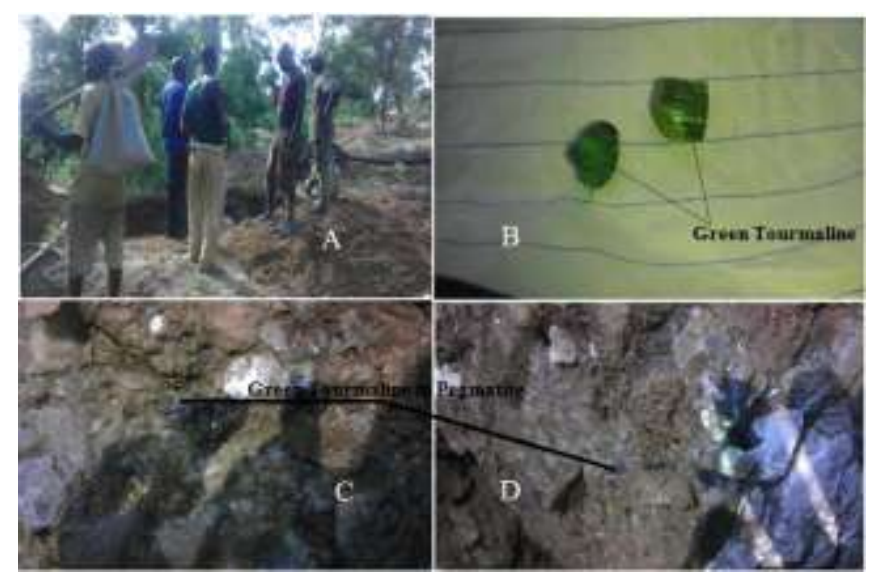

Plate 1: (A) mining activity within the survey area, (B) green tourmaline found in a pegmatite vein within the survey area, (C), (D) pegmatite vein in the survey area showing tourmaline occurrence.

\section{Method/Approach}

The Multiple Vertical Electrical Sounding (MVES) resistivity survey employing the 4 point electrode Schlumberger array along profile lines (Fig. 2) was used in this study. The fundamental requirements of any resistivity survey are the introduction of current and the measurement of voltage. Typically in this technique, two current and two voltage electrodes are used in arrays which are usually, but not necessarily, linear [10]. Electric current is passed into the ground through 2 outer current electrodes, and the resulting electric potential in the ground is measured by 2 potential electrodes to reveal the subsurface resistivity variations that may be caused by geological, hydrogeological or manmade variations.

Figure $2 \mathrm{~b}$ shows the MVES technique which involves rapid collection of multiple soundings along a profile line. The array is moved from position 1 to 2,2 to 3 and so on along the profile line after every set of data collected to desired depths using the Schlumberger configuration. The electrodes are arranged in collinear pattern and symmetrically about a centre point which is the point of investigation. A geometric factor is calculated as a function of the electrode arrangement and resistivity readings multiplied by it to give an apparent resistivity value. The electrode spacing is progressively increased, keeping the centre point of the electrode array in fixed position. The increase in current electrode spacing implies increase in depth of investigation e.g. L1, L2, L3 in figure 2. The red dots $1 \mathrm{a}, 1 \mathrm{~b}$, and 1c respectively illustrate the points of subsurface investigation

Volume 6 Issue 12, December 2017 www.ijsr.net 


\section{International Journal of Science and Research (IJSR) \\ ISSN (Online): 2319-7064}

Index Copernicus Value (2015): 78.96 | Impact Factor (2015): 6.391

with increasing current electrode spacing. This process of investigation is repeated along the entire profile line.

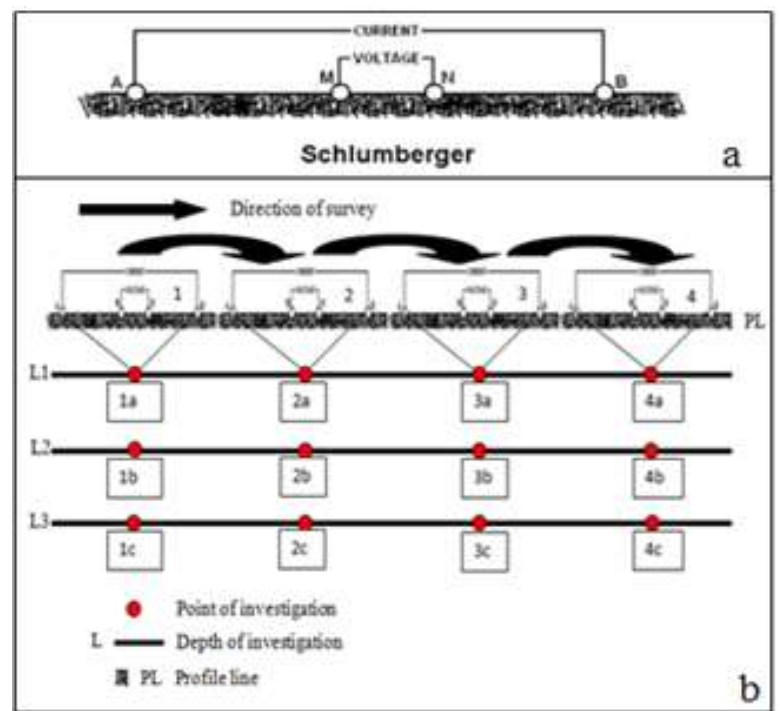

Figure 2: Schlumberger configuration (a), and MVES principle of operation (b)

Usually the vertical electrical sounding will reveal subsurface resistivity stratification i.e. resistivity variation with depth. The MVES approach investigates the way in which resistivity of the subsurface at the point of investigation varies with depth, and how it also varies laterally along the profile line. In this case, the approach assumes both the Vertical Electrical Sounding (VES), and the Horizontal Resistivity Profiling (HRP). This technique helps the geologist to delineate boundaries and structures based on the resistivity contrast between one area and the other in the subsurface.

Resistivity values were collected in different areas of surface exposures of pegmatite with the tourmaline mineralization, from areas also of migmatite exposure which is the host rock and finally from exposed weathered migmatite. The resistivity values within each of these areas were then averaged and used as control for this investigation. Table 1 shows the range of the averaged resistivity of each of the rocks in the area. In 3D resistivity surveys, electrodes are usually arranged in a square grid and the pole-pole array is usually used to make the potential measurement [11]. In this study, the survey area which falls within Longitudes 391843E and 392094E, and Latitudes 966477N and 966707N (all in Universal Transverse Mercator, UTME) was divided into grids, and data collected along 6 profile lines, PL1, PL2, PL3, PL4, PL5 and PL6 running in the Northeast-Southwest direction (Fig. 3) in conformity with the overall regional structural trend in the area. Points of sampling (stations) were then marked along each profile line and GPS readings of those points collected. The MVES was then conducted on each of these survey points along the entire profile lines.

Data was collected using the GEOTRON (model: G41) resistivity meter (plate. 2) with current electrode spread covering up to $200 \mathrm{~m}$ for every station investigated. The results for all resistivity data obtained from the field were interpreted by plotting apparent resistivity against array expansion on log-log paper and comparing the graphs with master curves types and their auxiliaries. This is a graphical interpretation technique that involves partial curve-matching procedure, which requires the use of one or more sets of auxiliary curves in conjunction with available two- and three-layer master curves [12]. This formed the basis for the use of computer inversion software (IX1D) in modeling the data [13-15], and the use of Rockware software to create a 2D geo-electric cross-section and a 3-D cube respectively that was useful in delineating both vertical and horizontal variations of subsurface resistivity layers, and therefore delineating potential zones of the tourmaline-rich pegmatite.

Table 1: Range of averaged resistivity values and interpreted lithologies in study area

\begin{tabular}{|l|l|}
\hline Range of resistivity $(\mathbf{\Omega m})$ & \multicolumn{1}{c|}{ Interpreted lithology } \\
\hline $10-200$ & Top overburden of clayey-sands \\
\hline $201-900$ & Fractured weathered basement \\
\hline $901-2800$ & Pegmatite \\
\hline$>2800$ & Consolidated basement \\
\hline
\end{tabular}

Figure 3: Base map of study area showing profile lines (PL1, PL2, PL3, PL4, PL5, PL6), VES stations, and line of section A-A

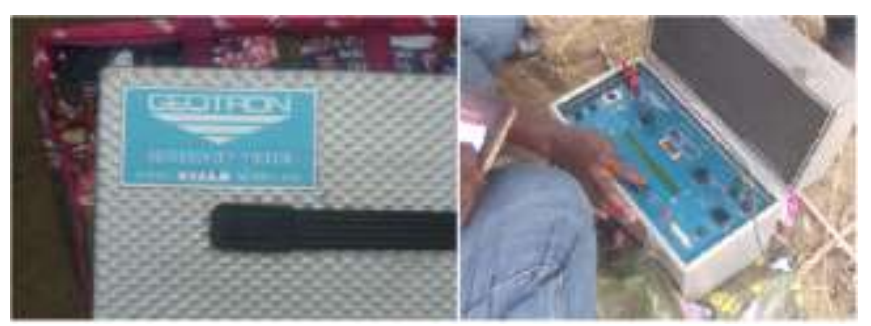

Plate 2: Resistivity meter used in the collection of data

\section{Results/Discussion}

The results here are presented as modelled resistivity data, $2 \mathrm{D}$ cross sections and $3 \mathrm{D}$ cubes to represent the subsurface materials (Figs. 4, 5, 6a and 6b). The interpretation of vertical electrical sounding (VES) data is based on the values of averaged resistivity value of each lithology typical in the area of study (Table1). Colour codes are adopted to differentiate the different lithologic units in the 2D and 3D models for easy interpretation. Orange, brown, purple and red are used to represent, top overburden, fractured/ weathered basement, pegmatite and consolidated basement, respectively. The side bar represents elevation in metres (m) above mean sea level (MSL).

\section{Volume 6 Issue 12, December 2017}

\section{www.ijsr.net}




\section{International Journal of Science and Research (IJSR)}

ISSN (Online): 2319-7064

Index Copernicus Value (2015): 78.96 | Impact Factor (2015): 6.391

Interpreted curves were of typical A, HK and HA types, and most of them showed four (4) basic geoelectric layers (Fig. 4).

The 2D cross section A- $\mathrm{A}^{\mathrm{I}}$ (Fig. 5) as well as the 3D model (Fig. 6a and 6b) reveals a typical NE-SW trend of the tourmaline-rich pegmatite. Overburden thicknesses range from $6 \mathrm{~m}$ to $18 \mathrm{~m}$, while the pegmatite thicknesses range from $10 \mathrm{~m}$ to about $60 \mathrm{~m}$. Fractured/weathered basement rock does not extend beyond $50 \mathrm{~m}$ from the surface, while consolidated basement extends from between $6 \mathrm{~m}$ in some areas and $50 \mathrm{~m}$ in others.

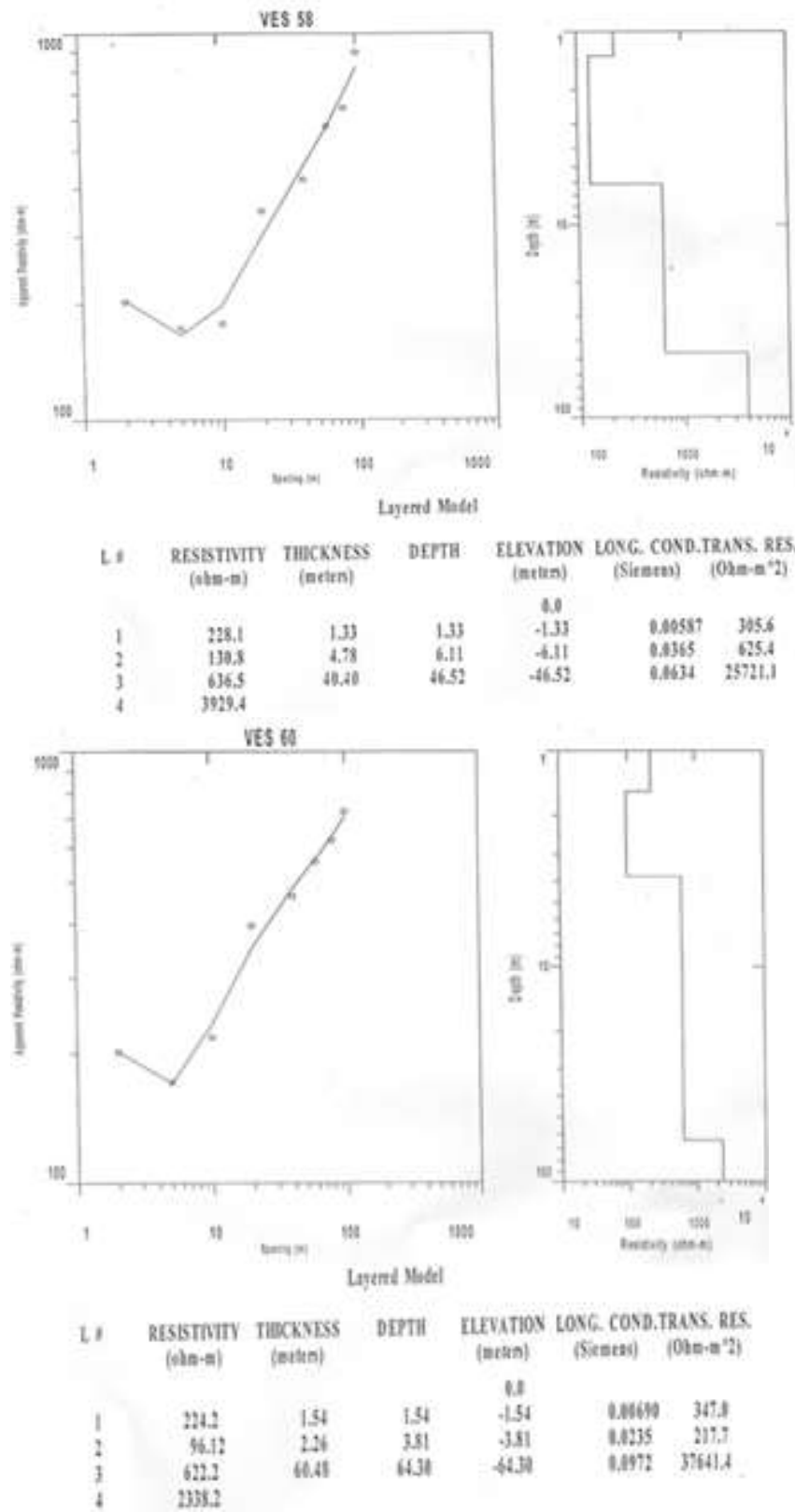

Figure 4: Samples of modeled and interpreted resistivity data (VES stations 58 and 60)

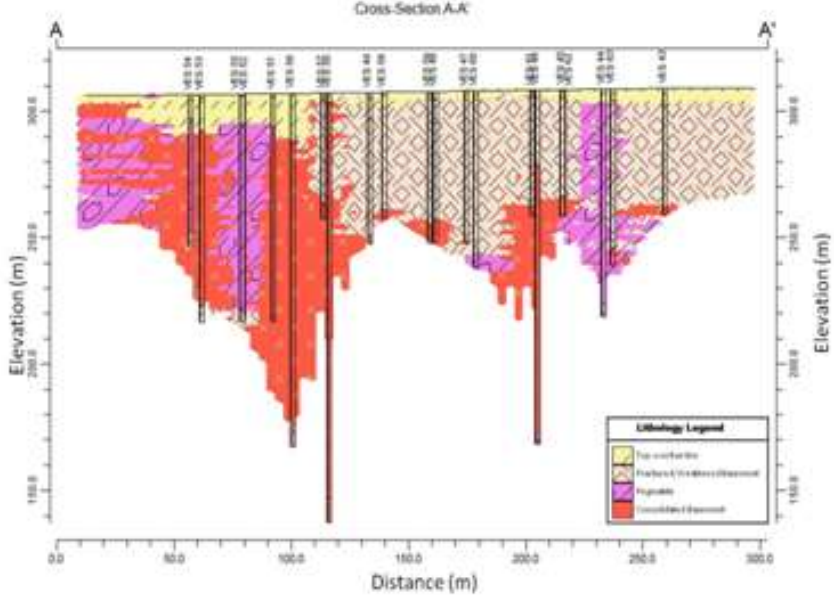

Figure 5: Cross section $(\mathrm{AB})$ of study area showing subsurface lithology

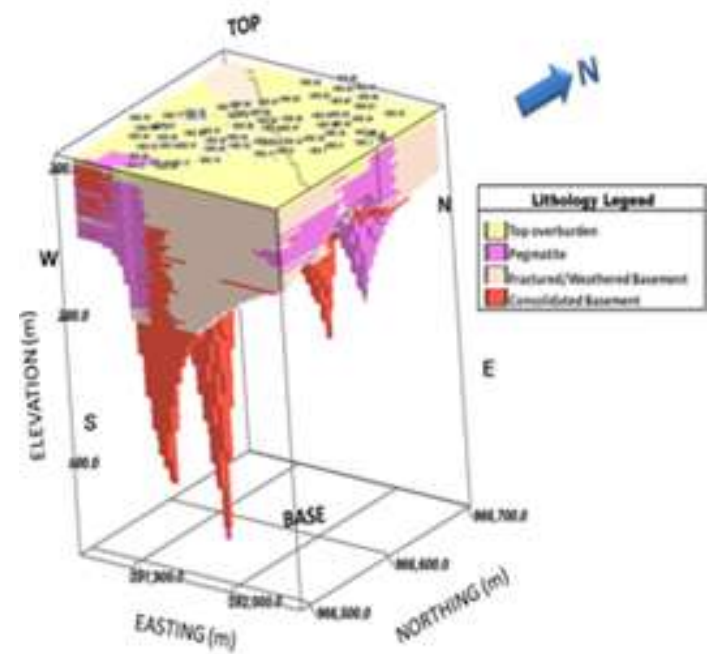

(a)

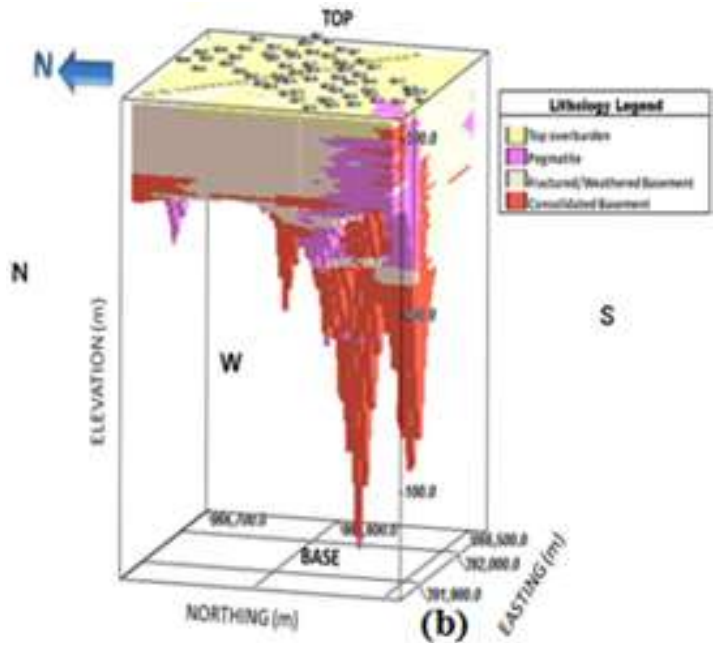

Figure 6: $3 \mathrm{D}$ resistivity models of the subsurface in study area (a) SE face (b) SW face

From the results, the area holds good prospects of green tourmaline hosted by the pegmatite intrusions in the area as evident in the result of the mining activities and the extent of the host pegmatite from the survey data. The concentration of mineralized pegmatite along the northeast/southwest portions of the area probably indicates that the pegmatite intrusion must have followed and filled structural features which may have developed during the Pan-African orogeny.

Volume 6 Issue 12, December 2017 www.ijsr.net 


\section{International Journal of Science and Research (IJSR)}

ISSN (Online): 2319-7064

Index Copernicus Value (2015): 78.96 | Impact Factor (2015): 6.391

\section{Conclusion}

3D geoelectrical resistivity survey using the Multiple Vertical Electrical Sounding (MVES) has been successfully used in this study to determine the extent of mineralized tourmaline-rich pegmatite within a mining site in AngwanDoka community in Kokona LGA, Nassarawa State, Nigeria. The modeling of resistivity data using a combination of manual curve matching, data inversion and iteration with IP2WIN software, and 3D data modeling using rockworks software, gave a good revelation of the trend and extent of the tourmaline-rich pegmatite. A major trend of the pegmatite was in the NE-SW direction which is in line with the overall regional structural trend in the region. The method can therefore be applied extensively for any resistivity related subsurface investigations.

\section{References}

[1] J. M. Reynolds, "An Introduction to Applied and Environmental Geophysics", John Wiley \& Sons Ltd., Baffins Lane, Chichester, West Sussex PO19 IUD, England, Pp. 418-490, 1997.

[2] W. M. Telford, L. P. Geldart and R. E. Sheriff, "Applied Geophysics (2 $2^{\text {nd }}$ Edition)", Cambridge University Press. Pp. 283-288, 1990.

[3] P. W. Mc Dowel, "Geophysics in Engineering Investigation", Construction Industry Research and Information Association (CIRIA). Pp. 61, 2002.

[4] J. Milsom, "Field Geophysics- The Geological Field Guide Series ( $3^{\text {rd }}$ Edition)", John Wiley \& Sons Ltd. Atrium, Southern Gate, Chichester, West Sussex PO19 8SQ, England, pp. 97-116, 2003.

[5] P. Kearey, M. Brooks and I. Hill, "An Introduction to Geophysical Exploration ( $3^{\text {rd }}$ Edition)", Blackwell Science Ltd., pp. 183-196, 2002.

[6] A. Pidlisecky, H. Eldad and R. Knight, "RESINVM3D: A 3D Resistivity Inversion Package", Geophysics, 72 (2). Pp. H1-H10. 2007.

[7] T. Dahlin and M.H. Loke, "Quasi-3D Resistivity Imaging- Mapping of Three Dimensional Structures using Two Dimensional DC resistivity techniques", $3^{\text {rd }}$ EEGS Meeting. EEGS. 1997.

[8] I. Clark,"Practical Geostatistics", Geostokos Limited, Alloa Business Centre, Whins Road, Alloa, Central Scotland FK103SA. Pp. 5-6, 1979.

[9] "Physical Setting of Nassarawa State", http://www.onlinenigeria.com/nassarawastate/?blurb=324 2/5/2003 12:49:34 PM

[10] J. Milsom and A. Eriksen, "Field Geophysics- The Geological Field Guide Series (4 ${ }^{\text {th }}$ Edition)", John Wiley \& Sons Ltd., 2011.

[11] M. H. Loke and R.D. Barker, "Practical Techniques for 3D Resistivity Surveys and Data Inversion", Geophysical Prospecting. Vol 44, No. 3. Pp. 499-523, 1996.

[12] A. A. Zohdy, "The Auxiliary Point Method of Electrical Sounding Interpretation and its Relations to Dar Zarrock Parameters", Geophysics, 30. Pp. 644660, 1965.

[13] R. T. Verave, N. Mosusu and P. Irarue,"1D Interpretation of Schlumberger DC Resistivity Data from the Talasea Geothermal Field, West New Britain
Province, Papua New Guinea", Proceedings World Geothermal Congress 2015 Melbourne, Australia, 1925 April 2015.

[14] S. O. Ariyo and A. A. Banjo,"Application of Electrical Resistivity Method for Groundwater Exploration in a Sedimentary Terrain. A Case Study of Ilara-remo, Southwestern Nigeria" Continental Journal. Earth Sciences.

[15] P. O. Odong, "Groundwater Potential Evaluation and Aquifer Characterization using Resistivity Method in Southern Obubra, Southeastern Nigeria", International Journal of Environmental Sciences. Vol 4, No.1, 2013. Pp. 96-105.

\section{Author Profile}

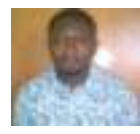

Oyonga Augustine Oyonga received the B.Sc. and M.Sc. degrees in Geology and Petroleum Geophysics from the Department of Geology, University of Calabar, Calabar, Nigeria in 2004 and 2010, respectively. He also holds a certificate in Hydrogeophysics and Water Well Drilling, and has undergone several trainings in software applications (Petrel, Opendtect etc). He is currently a lecturer and a $\mathrm{PhD}$ student in the Department of Geology, University of Calabar, Calabar.

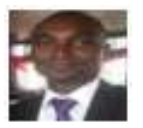

E. A. Kudamnyais currently a lecturer in the Department of Geology, University of Calabar, Calabar, Nigeria. He holds B.Sc. and M.Sc. degrees in Geology from the Ahmadu Bello University, Zaria. His area of specialization is Hydrogeology and Geological Remote Sensing.

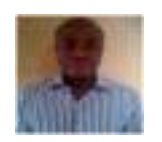

S. I. Ugar holds B.Sc. (2003) and M.Sc. (2010) degrees in Geology and Petroleum Geophysics respectively from the Department of Geology, University of Calabar, Calabar, Nigeria. $\mathrm{He}$ is currently a lecturer and a PhD student in Structural Geology and Geophysics. 